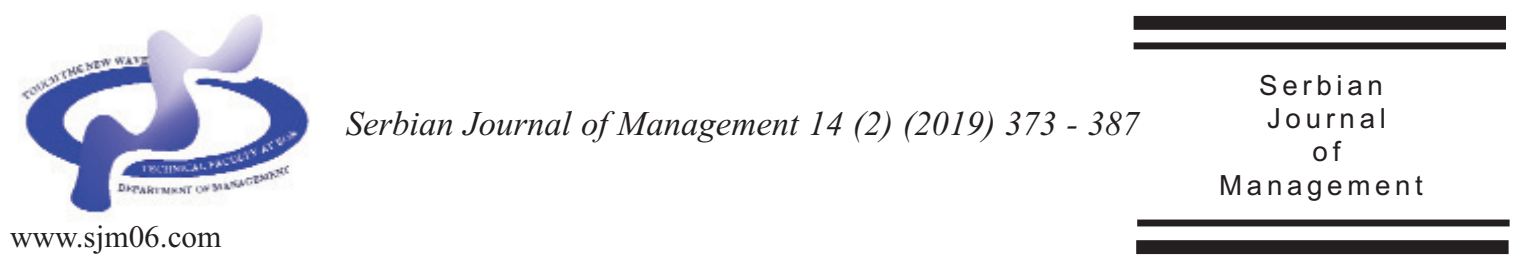

\title{
OPTIMIZATION OF INVESTMENT PORTFOLIO MANAGEMENT
}

\author{
Viktor Oliinyk $^{\mathbf{a}^{*}}$ and Olga Kozmenko ${ }^{\mathrm{b}}$ \\ a Department of Economic Cybernetics, \\ Sumy State University, 57, Petropavlivska Str., Sumy, Ukraine, 40000

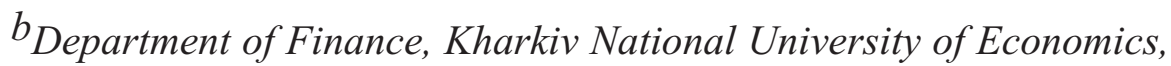 \\ Nauky avenue, 9-A, Kharkiv, Ukraine, 61166
}

(Received 12 March 2018; accepted 02 April 2019)

\begin{abstract}
The task of creating an investment portfolio by a financial institution is considered. Funds for creating a portfolio are taken from two sources: enterprise's equity funds and borrowed funds. Optimization of the created portfolio is performed. A portfolio of maximum efficiency was obtained with restriction on the measure of risk, which is specified in the form of a VaR indicator. Using optimization portfolio data, a model of portfolio asset management is being built. Using the Pontryagin maximum principle, optimal strategies of its participants are determined. The optimal function of managing the investment portfolio in the form of a share of the income received is found. Numerical results of optimal management of investments in a financial portfolio from the financial institution as well as from the creditor are presented.
\end{abstract}

Keywords: management, optimization, investment, asset, VaR

\section{INTRODUCTION}

When creating an investment portfolio, certain financial resources are needed. To form an effective portfolio, a financial institution (enterprise) lacks equity funds, and it attracts external investors to use borrowed funds. In a joint investment project, every participant has his own financial interests and determines his strategy of participation in this project. Therefore, external investors invest money in such a project to obtain additional profit as well as the financial institution expects to get the maximum net profit.

The purpose of this study is to develop a strategy for creating an investment portfolio and its further management, taking into

* Corresponding author: oliynyk.viktor@gmail.com

DOI: 10.5937/sjm14-16806 
account financial interests of all its participants. The main tasks to be considered in this article are as follows: construction of an investment portfolio based on the Markowitz theory; task formulation for the optimal management of financial assets using the Pontryagin maximum principle; formulation of interests for all the participants of the system; use of the utility function to construct the objective function; finding the optimal control function (OCF); obtaining the results of numerical experiments.

A new investment portfolio is assumed to be created. The portfolio suggests every participant to have his own quota, which is maintained throughout the entire period of the project's existence. To create an investment portfolio of maximum efficiency, the Markowitz model (1952) is used. In his work, Markowitz introduces the concept of risk in the form of standard deviation and forms a portfolio considering this index. In this paper, it is proposed to form an investment portfolio, where Value-at-risk $(\mathrm{VaR})$ is used as an indicator of risk. It should be noted that this indicator reflects the amount of losses for a certain period in money terms.

Having formed the optimal portfolio of maximum efficiency with regard to the restrictions on possible financial losses, the financial development of this project should be implemented for some time. Depending upon the funds invested and the financial interests of each of the participants, the stages of attracting monetary resources should be made up. Thus, an initial project is being developed. One of the methods of optimal management of the acquired investment project is the one based on the Pontryagin maximum principle (Pontryagin et al., 1962). It is proposed to use this method to manage investors' financing. The objective in this formulation is reduced to a differential game with no opposing interests regarding the financial institution (enterprise) and external investors (Germeier, 1976).

\section{LITERATURE REVIEW}

Many authors studied the formation of an optimization portfolio, which would consist of risk and risk-free financial instruments. One of the main criteria for building a portfolio is its risk index. To build optimization models and risk analysis, Shalit \& Yitzhaki (1984) suggested using the Mean-Gini (MG) method, which is simple in its practical application.

In their work, Kalayci et al. (2019) analyze the results of research on the formation of an optimal securities portfolio. Much attention is paid to algorithms and methodologies based on the use of computer technology. A review of the previously constructed portfolios that improve the standard portfolio in a deterministic formulation was made. Based on a comprehensive review, a future research area is proposed in this area.

Bender et al. (2019) propose building portfolios of factors based on average values of variance. In their work, they analyze portfolios based on alternative weighting schemes. It is shown that the portfolios of factors describe the information more fully due to the explicit use of input factors. Danko \& Šoltés (2018) in their work proposes to form an investment portfolio based on Markowitz theory in combination with graph theory. Testing of the resulting portfolios was carried out using simulation analysis. The results can be used by 
individual investors in the formation of the optimization portfolio.

Zhou et al. (2019) consider the optimal investment portfolio at risk of a jump over time. It is shown that for the formation of the optimization portfolio important indicators are: the initial intensity of the jump, the dynamics and stability of the jump. Formed investment portfolio provides good out-ofsample performance.

Calvo et al. (2018) propose to form an investment portfolio based not only on historical data. For this purpose, it is proposed to use the concept of value information. This indicator reflects investor confidence in his non-historical data. The level of risk outside the historical interval is proposed to be adjusted with the help of diversification restrictions. Lester (2019) builds a portfolio based on the theory of factor investment. A comparison is made between a set of single-factor investment portfolios and a single integrated portfolio. It is shown that the integrated portfolio more accurately analytically predicts profitability and risk in subsequent investment periods.

The application of portfolio theory in insurance is presented in Oliynyk (2015). An algorithm for obtaining an optimization portfolio of the insurance company is presented. For real data, the optimal composition of the investment insurance portfolio of minimum risk by type of insurance was obtained. As limitations of the task, the main indicators of the insurance company's financial activities are used.

Uhl and Rohner (2018) proposes to introduce a compensation portfolio that optimizes asset allocation and related risks. The proposed approach allows for the optimization of portfolio parameters using both the theory of behavioral portfolio and modern portfolio theory. Post et al. (2018) consider portfolio optimization based on an empirical likelihood estimation method and a criterion for making a decision on stochastic dominance. This approach is implemented in two stages: the necessary probabilities are found using convex programming; with the use of linear programming formed an optimization portfolio. The resulting portfolio gives good results for the out-ofsample impulse strategy. Grinblatt and Saxena (2018) propose to improve the accuracy of determining the pricing of imitating factors by obtaining a single portfolio by combining basic portfolios. This approach can also be used for portfolios with anomalies.

Since the mid-1990s, researchers began using the Value-at-Risk (VaR) indicator as a market risk. Holton (2003) publishes a book about the use of the VaR indicator at the real trading floors. In his publication, he shows how to design and implement this indicator in real time mode.

Basak and Shapiro (2001) analyzed the use of VaR criteria by managers while forming the dynamic optimization portfolios. They found out that risk managers using VaR opted for a risky portfolio management strategy and, therefore, their activities could lead to significant financial losses. To minimize these losses, they proposed an alternative risk management strategy based on the expectation of losses. Zhang et al. (2019) in their article for the analysis of maximum loss, they propose to use the double-VaR indicator. This indicator summarizes the obtained values of the standard one-dimensional VaR. The twodimensional income-risk confidence domain is analyzed for two models. Francq and Zakoïan (2018) considers a dynamic model of changes in the composition of assets and conduct a joint assessment of market and 
appraisal risks in the formed portfolio. Under the conditions of elliptic distribution, the value of $\mathrm{VaR}$ acts as a measure of risk. We also study filtered historical modeling, a research method that allows for more general distribution conditions. A portfolio with minimal variance is explored in more detail. The advantages and disadvantages of the considered approaches are analyzed.

Burdorf and Van Vuuren (2018) in their study analyzes the market behavior of risk measures VaR and Expected Shortfall (ES). Considering the stock portfolio, it is shown that finding these indicators by the Monte Carlo method and the dispersion-covariance method is preferable to methods based on historical data. Rockafellar and Uryasev (2002) suggested using conditional value-atrisk (CVaR) as a measure of risk. This criterion makes it possible to obtain risk assessments that do not fully reflect the VaR indicator. When applying this indicator, a modern mathematical apparatus should be used and computational experiments carried out.

To model investors' behavior, the utility function could be used. This function must meet certain requirements and it reflects the attitude to the risk of the person making the decision. Blanchett and Ratner (2015) introduce a new utility function that includes the risk of a decline. This function is used when forming an optimal portfolio for an investor focused on income generation.

Maheshwari and Sarantsev (2018) is considering an optimal risk management model. The investors are private entities that borrowed money from the central bank at a controlled interest rate. It is assumed that each of the participants of the investment project seeks to improve their well-being: a private entity through the maximization of the expected logarithmic wealth; central bank - maximizing the exponential utility function. An explicit solution of optimal control problems is given. Bilbao-Terol et al. (2016) propose a mathematical model based on targeted programming, which covers the theory of investment portfolio with mental accounting and responsible investment. The share participation of each investor is proposed to be assessed by an expert method taking into account fuzzy rules. Mei and Nogales (2018) explores the behavior of a multi-period investor when choosing a portfolio. The optimality criterion is its maximum utility of intermediate consumption, which depends on risky assets, costs and predictable profitability. An optimal consumption algorithm is proposed based on the proposed suboptimal plans.

For successful functioning of a financial enterprise, it is necessary to form an investment portfolio as well as to develop and manage it in the best possible way.

Van Gelderen et al. (2019) analyze the management strategy of a mutual investment fund using the factor investment theory. On the basis of the conducted studies, it was shown that the buy-and-hold strategy together with the choice of a multifactorial manager is more profitable than the tactics of active fund management. Del Guercioa et al. (2018) study the effectiveness of portfolio management, consisting of three types of accounts: hedge funds, mutual funds and separate accounts. In their studies, they confirm the hypothesis of a conflict of interest with the parallel management of the created portfolio.

Li et al. (2018) consider the problem of describing the profitability of assets using non-parametric programming. An approach based on the Fama - French three-factor model is proposed: cost, size and market factor. For each factor, transformations are 
constructed, the necessity of which is verified by a generalized criterion of the maximum likelihood hypothesis. The proposed approach is tested on real data and samples of finite sizes. Simonian and $\mathrm{Wu}$ (2019) learn replication hedge funds when investing. For accurate replication, it is proposed to use the ridge regression method. This method allows to obtain a generalized model that most adequately analyzes the risks and improves the basic factorial models of hedge fund replication based on ordinary least squares (OLS) regression.

García-Melón et al. (2016) consider a financial asset with a social responsibility (SR). SR involves finding the various criteria and their weights in the asset under investigation. When finding these parameters, it is necessary to take into account the preferences of each investor. In this article, the authors suggest using the Analytic Hierarchy Process to determine weights.

One of the methods for optimal control of dynamical systems is the one based on the Pontryagin maximum principle. Many authors used this principle in their scientific works. Koopmans (1967) reviewed the results of economic growth models based on the Pontryagin maximum principle. He also examined the obstacles that arise when applying this method and suggested directions for further research. Shell (1969) in his work considered the application of the Pontryagin maximum principle in the economy.

Kamien and Schwartz (1971) showed that the Pontryagin method could be applied to the problems arising in economic analysis. They have proved the theorem concerning the properties of the state variables of the system, which makes it possible to obtain the optimal control solution for a certain class of economic issues.
The article Oliinyk (2017) discusses the problem of optimal control of the distribution of gross product when considering a single-productive economic system. The control function is the value of the share of the gross product, aimed at nonproductive consumption. Analyzes the switching point of investment at which the company will receive the maximum income. To solve this problem, the Pontryagin maximum method is used.

Hartl et al. (1995) considered various forms of the Pontryagin maximum principle for optimal management issues with restrictions on state variables. On the illustrative examples, they showed the application of these optimal forms for solving managerial tasks.

Aseev et al. (2005) studied the model of endogenous growth of two countries, based on the Pontryagin maximum principle. It is shown that one of the countries develops due to the absorption of some knowledge obtained in the leading country. The work of Aseev and Kryazhimskii (2007) is dedicated to the theoretical aspects of the Pontryagin maximum principle for solving optimal management tasks arising in the economy when studying the processes of economic growth. Aseev (2014) considered application of the Pontryagin maximum principle for a class of optimal management tasks with an infinite horizon that appears when studying the economic growth processes.

Krasovskii and Tarasyev (2008) considered the task of optimal management with the functional given by the improper integral. This task arises when considering models of economic growth. The proposed algorithm, based on the Pontryagin maximum principle, makes it possible to obtain optimal trajectories for real macroeconomic data. 
Artstein (2011) formulated some issues arising from the application of the Pontryagin maximum principle and suggested extending the scope of this method to the variations calculus.

The considered literary sources mainly reflect the methodology for creating an optimal investment portfolio, as well as applying the Pontryagin maximum principle to the economic research. Therefore, methods for creating and managing an investment portfolio should be considered.

\section{RESEARCH METODOLOGY}

In the research, an approach based on the Pontryagin maximum principle is applied. This method is universal and allows obtaining optimal management for financial resources of an enterprise. A financial portfolio of an institution is formed based on the Markowitz portfolio theory. The VaR indicator is used as a criterion of risk assessment, which reflects financial losses in monetary terms. Applying this indicator in the formation of an investment portfolio allows assessing its quality in real monetary units. The yield of a formed portfolio is determined by the set of its securities taking into account a risk component.

Management of a formed portfolio should be carried out considering the interests of all its participants. An evaluation criterion is represented by the net present value (NPV). Consideration of a discounting multiplier of NPV allows assessing the quality of a portfolio obtained on the studied interval of the project functioning. To find the objective function, a mathematical apparatus based on utility theory is used. Analysis of the Hamiltonian function, allows to obtain OCF in an analytical form. The problem in this formulation reduces to solving a system of differential equations with respect to the function of assets and the auxiliary function. This solution allows a financial enterprise and an external investor to receive the maximum profit return from the invested financial resources.

\section{THEORETICAL FOUNDATION}

\subsection{Investment portfolio formation}

The issue of managing the funds invested in fixed assets of an enterprise was considered by Germeier (1976) and Pavlov (2004). In this paper, management of an investment portfolio is considered.

A financial institution creates an investment portfolio in order to obtain maximum profit from the funds invested in it. The organization can use its financial resources, as well as attract external investors. A financial organization takes advantage of the total income from the portfolio functioning. An external investor receives income in the form of dividends from his share in the portfolio, as well as interests from the invested funds. Thus, the formation of an investment portfolio, which participants are a financial organization (enterprise) and an external investor is considered.

A portfolio of maximum efficiency on a basis of the portfolio theory of Markowitz (1952) is compiled. Availability of original capital to create a portfolio is considered

$$
A_{0}=\kappa V_{0}+(1-k) U_{0}(0 \leq k \leq 1)
$$

where

$V_{0}$ - equity funds of an enterprise; 
$U_{0}$ - external investor's funds;

$k$ - share of the financial institution in the assets of the investment portfolio.

This share in the distribution of funds can vary throughout the process of investing in the portfolio $\left[t_{o} ; T\right]$.

When forming a portfolio it is necessary to find the shares of original capital distribution, which maximize the expected efficiency of portfolio $E_{p}$, taking into account the effectiveness of its individual components. Herewith the index of portfolio risk is ensured to be no more than VaR* and the balance condition is fulfilled in the form of $\sum^{n} x_{i}=1$. When forming such a portfolio, systematic risks and the investor's attitude to risk are not considered. A portfolio includes only risk assets.

A portfolio of maximum efficiency is acquired:

$$
\begin{aligned}
& E_{p}=\sum_{i=1}^{n} x_{i} E_{i} \rightarrow \max \\
& \left\{\begin{array}{l}
\sqrt{P \operatorname{VaR}^{T} \Omega P V a R} \leq \operatorname{VaR}^{*} \\
\sum_{i=1}^{n} x_{i}=1 \\
x_{i} \geq 0
\end{array}\right.
\end{aligned}
$$

where

$P V a R$ - vector-column of individual position risks;

$\Omega$ - correlation matrix.

Having found the optimization task (2), the solution should be analyzed and optimal portfolio management should be considered. Management consists of decision-making on the additional investment of portfolio, from a financial institution as well as from an investor. At the same time, investors' strategies should be mutually beneficial and are considered on a time interval $\left[t_{o} ; T\right]$.

\subsection{Investment portfolio management}

\subsubsection{Problem setting of the portfolio management}

The development of an investment project is assumed to occur according to some mathematical model. A differential equation of the dynamics of changes in assets is determined:

$$
\frac{d A(t)}{d t}=\mu(t) A(t)+V(t)+U(t)
$$

where

$\mu(t)$ - intensiveness of assets growth;

$V(t)$ - enterprise's investments at time $t$;

$U(t)$ - external investor's investments at time $t$.

The number of assets at the initial time is known (1)

$$
A\left(t_{0}\right)=A_{0}
$$

We will find the income received from the formed investment portfolio:

$D(t)=E_{p}(t) A(t)$

where

$E_{p}(t)$ - portfolio efficiency taken from the optimization task solution (2).

We introduce the following functions: a management function $0 \leq v(t) \leq 1$, that shows how much of the income is reinvested into portfolio assets; the function of dividends $0 \leq d(t) \leq 1$ which determines what percentage of revenue goes to pay dividends.

The strategy of a financial institution is to obtain the maximum discounted net present value (NPV), and the strategy of the external 
investor is to obtain the maximum profit in the form of the difference between the discounted dividends and the discounted investments in portfolio assets. To unite the interests of the participants in the investment project, we introduce the utility function in the form (Mas-Colell et al., 1995):

$$
W(t)=1-\exp [-x(t)]
$$

where

$x(t)=x_{1}(t)+x_{2}(t) \quad$ - function reflecting financial interests of project participants:

$x(t)=\exp [-\delta(t) t]\{D(t) k(1-v(t)-d(t))$

$+D(t)(1-k)(d(t)-v(t))\}$

where

$\delta(t)$ - discount coefficient.

The target function of the proposed model is:

$J=\int_{t_{0}}^{T} W(t) d t+\alpha A(T) \rightarrow \max$

$$
\begin{aligned}
& \frac{d \Psi(t)}{d t}=-\frac{\partial H(t)}{\partial A}=-\left\{\Psi(t)\left[\mu(t)+E_{p}(t) \nu(t)\right]\right. \\
& +\exp [-y(t) A(t)] y(t)\}
\end{aligned}
$$

where

$$
\begin{aligned}
& y(t)=\exp [-\delta(t) t] E_{p}(t)(k(t) \\
& +d(t)-v(t)-2 k(t) v(t)
\end{aligned}
$$

For auxiliary function, the transversality condition is held true

$$
\Psi(T)=-\alpha
$$

Investigating the Hamiltonian function (9) to an extremum in the control variable, we obtain OCF in the form:

$V^{*}(t)=\frac{\ln [\Psi(t)]+\exp [-\delta(t) t] E_{p}(t) A(t)[k(t)+d(t)-2 k(t) d(t)]+\delta(t) t}{E_{p}(t) A(t) \exp [-\delta(t) t]}$

As a result, we obtain the solution of the problem in the form of a system consisting of the following relations: (3), (4), (10), (12), (13). The solution of the obtained system is carried out by a numerical method.

\section{RESULTS}

Each financial company creates its

To solve the set task (3), (4), (8) the Pontryagin maximum method (Pontryagin et al., 1962) is applied. The Hamiltonian function should be written down as follows:

$$
H(t)=\Psi(t)\{\mu(t) A(t)+v(t) D(t)\}+W(t)
$$

where

$\Psi(t)$ - auxiliary function satisfying the equation individual portfolio, which reflects: its attitude to risk; the amount of funds attracted and their ratio between external investors; distribution of income received; the period of existence of an investment project when its optimal management takes place, etc. Each of these parameters can be specified and the appropriate timeframes for the optimal control investment of this project can be found analytically for a financial institution as well as for external investors. 
As a numerical experiment of the obtained optimization management task, the following initial data are considered, which are constant: period of the investment portfolio management $\quad(\mathrm{T}=10)$; the amount of the investment portfolio in the initial $\left(t_{0}=1\right)$ and final time $(t=T)$ are respectively $A(1)=5$ units. $A(10)=15$ units; the growth rate of financial assets $(\mu=0.5)$. Table 1 shows the various options for translating the dynamic system from a given initial state to a given final state.

Having the initial data, investment project strategies for its participants are considered. To do this, the numerical values should be inserted into the corresponding equations and the obtained results should be analyzed.

Figure 1 - Figure 5 shows the optimal management of the investment portfolio for various dependencies between its parameters.

\subsection{Analysis of the obtained results}

Figure 1 shows the distribution of OCF for a given return on the financial portfolio $\left(E_{p}=0.25\right)$, the absence of dividend payments $(d=0)$ and the discount factor $(\delta=0)$. An analysis of the solution obtained shows a decreasing trend in the investment of additional funds. If the portfolio consists only of the assets of the financial institution $(k=1)$, then in the initial period of the project's investment, the share of income is larger compared to the portfolio created only from the external investor's funds $(k=0)$. This

Table 1. Strategies for the formation of the investment portfolio

\begin{tabular}{|c|c|c|c|c|c|}
\hline Option & $k(t)$ & $d(t)$ & $E_{p}(t)$ & $\delta(t)$ & $\lambda$ \\
\hline \multirow{3}{*}{1} & 0 & \multirow{3}{*}{0} & \multirow{3}{*}{0.25} & \multirow{3}{*}{0} & -1.474 \\
\hline & 0.6 & & & & -0.172 \\
\hline & 1 & & & & -0.042 \\
\hline 2 & 0.6 & 0.3 & 0.25 & 0 & -0.213 \\
\hline \multirow{3}{*}{3} & \multirow{3}{*}{0.6} & \multirow{3}{*}{0} & 0.2 & \multirow{3}{*}{0} & -0.264 \\
\hline & & & 0.25 & & -0.172 \\
\hline & & & 0.3 & & -0.114 \\
\hline \multirow{3}{*}{4} & \multirow{3}{*}{0.6} & \multirow{3}{*}{0.3} & \multirow{3}{*}{0.25} & 0 & -0.213 \\
\hline & & & & 0.05 & -0.197 \\
\hline & & & & 0.1 & -0.175 \\
\hline \multirow{3}{*}{5} & \multirow{3}{*}{$0.0777 t+0.0223$} & \multirow{3}{*}{$0.0333 t-0.0333$} & \multirow{3}{*}{$0.0222 t+0.0778$} & 0 & -0.341 \\
\hline & & & & 0.05 & -0.287 \\
\hline & & & & 0.1 & -0.235 \\
\hline
\end{tabular}

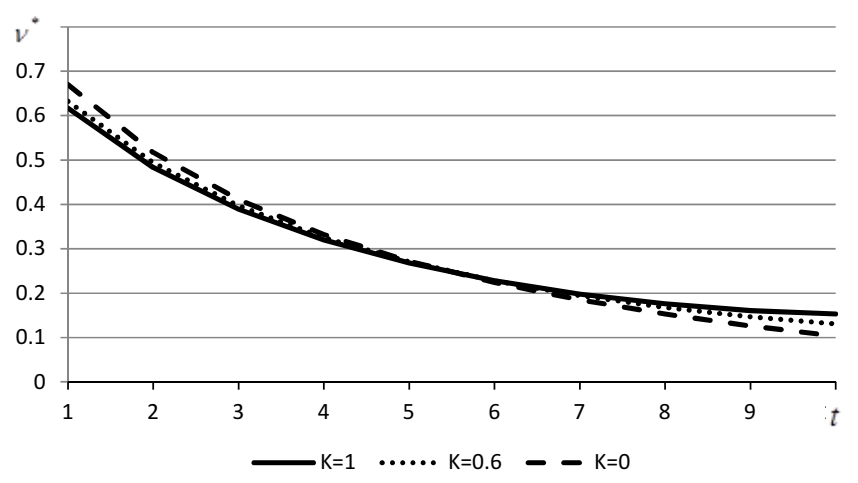

Figure 1. The distribution of the optimal control function (Option 1) 


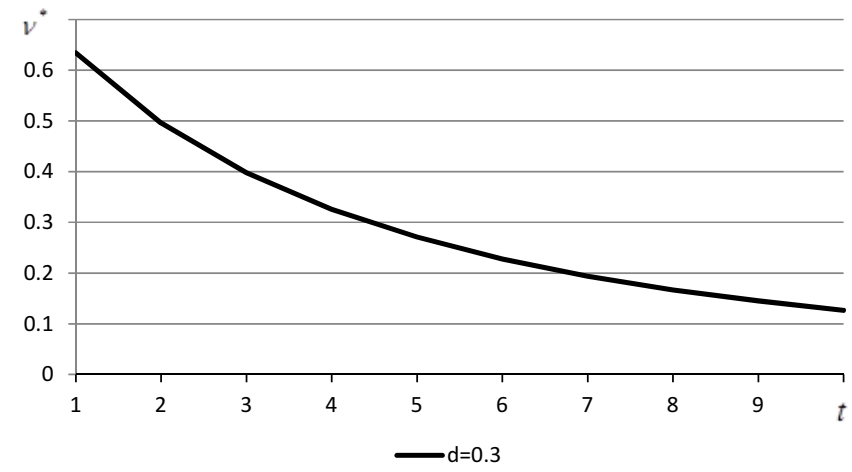

Figure 2. The distribution of the optimal control function (Option 2)

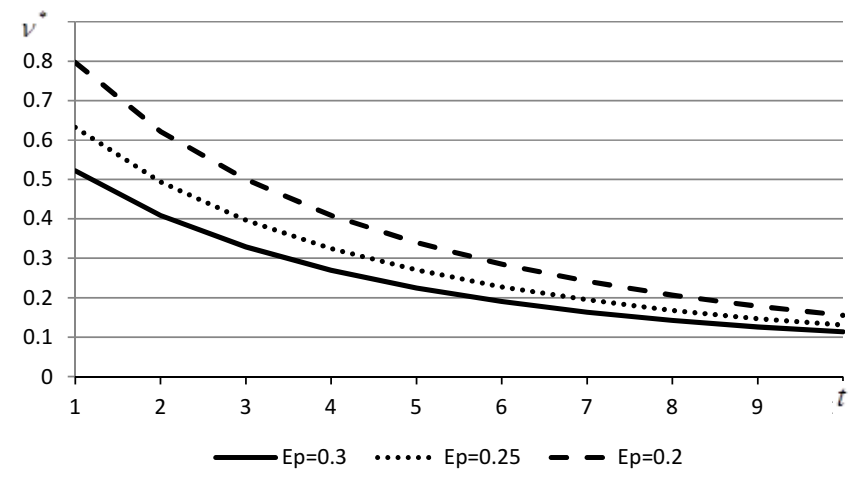

Figure 3. The distribution of the optimal control function (Option 3)

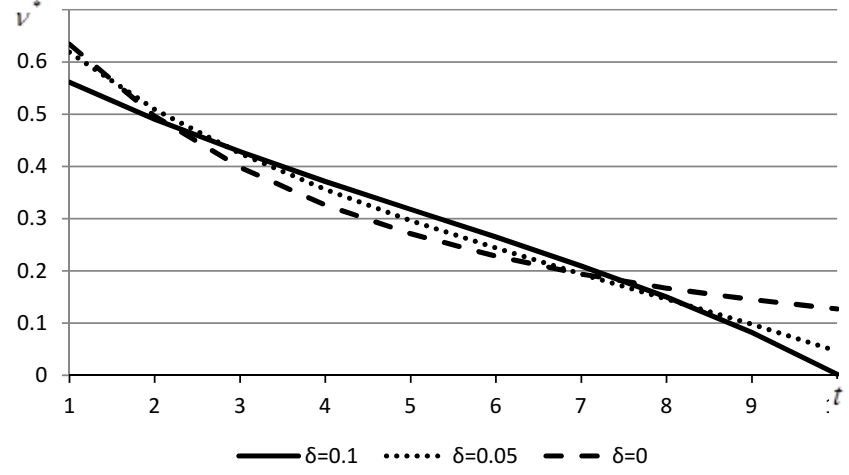

Figure 4. The distribution of the optimal control function (Option 4)

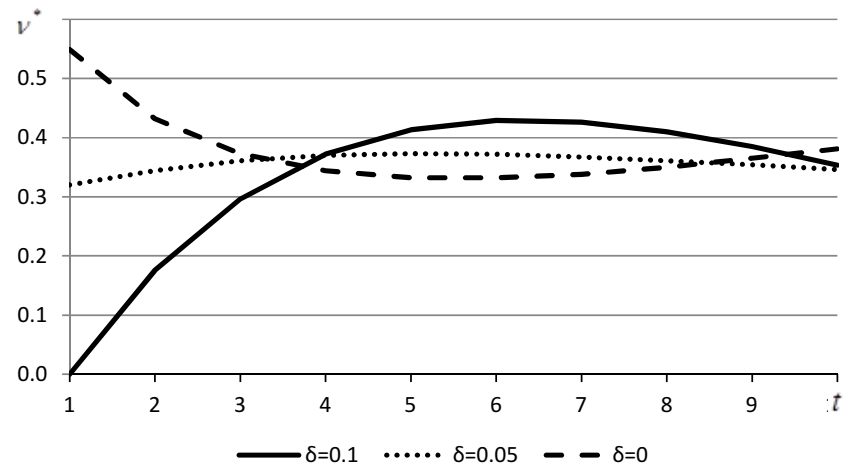

Figure 5. The distribution of the optimal control function (Option 5) 
ratio is reversed, when the portfolio is formed at the end of the investment period.

Figure 2 shows the distribution of OCF for a dividend payment option in the amount of $30 \%$ of revenue, the ratio between investors' financial investments $(k=0.6)$, the portfolio's constant return $\left(E_{p}=0.25\right)$ and in the absence of a discounting indicator $(\delta=0)$. Studies have shown that the distribution of OCF dividend payout in the range of $0-0.3$ practically did not have a significant impact. Analysis of the obtained ratio (13) shows that with equal distribution of funds between investors, the ratio taking into account the dividend policy does not affect the distribution of OCF over the whole period of investment of the financial portfolio.

When managing a portfolio of greater profitability, it is necessary to invest less investment in its development. This result is confirmed by the numerical experiment shown in Figure 3. For different portfolio profitability options $E_{p}(0.2 ; 0.25 ; 0,3) \mathrm{OCF}$ has the character of a decreasing curve.

The results of the conducted studies showed that, the discounting factor has a significant effect on the distribution of OCF. Figure 4 shows that with an increase in the discount rate from 0 to 0.1 , the share of financial receipts in the investment portfolio decreases. The remaining parameters of the proposed model are constant. Particular attention should be paid to the study of the influence of the discounting factor on the formation of a dynamic investment portfolio. Figure 5 shows the distribution of OCF, depending on the discount factor $\delta(0 ; 0.05$; $0,1)$. When studying the character of the OCF distribution, it was taken into account that the parameters of the model in the investment interval $\left[t_{o} ; T\right]$ increase linearly, namely: $k$ from 0.1 to $0.9 ; d$ from 0 to $0.3 ; E_{p}$ from 0.1 to 0.3 . The nature of the distribution of OCF shows that the discount factor significantly affects the formation of the investment portfolio. This is especially pronounced in the initial period of investment. At later stages of portfolio creation, the effect of this indicator is less evident.

\section{DISCUSSION}

Formation and creation of an investment portfolio can be carried out by various methods. Markowitz (1952) proposed to create a portfolio of securities considering the risk. As a measure of risk, he suggested to use the standard deviation. A portfolio risk assessment can also be performed based on other indicators. Basak and Shapiro (2001) analyzed the use of the VaR risk indicator by risk managers when managing a dynamic portfolio and proposed an alternative risk management model based on the expectation of losses. In his work, Holton (2003) pays great attention to the $\mathrm{VaR}$ indicator and describes how to use it and implement it as a market risk when forming a portfolio. Rockafellar and Uryasev (2002) propose using conditional value-at-risk (CVaR) as a measure of risk and demonstrate its advantages compared to the VaR indicator. Shalit and Yitzhaki (1984) proposed to use the Mean-Gini (MG) method to construct an optimization portfolio. Analyzing proposed approaches to the risk assessment when constructing a financial portfolio, the VaR indicator should be used as a restriction on the amount of risk in order to form a portfolio of the greatest efficiency.

One of the methods for controlling a dynamical system is the Pontryagin maximum principle. Koopmans (1967) 
analyzed the results of studies on the application of this principle in the models of economic growth and showed possible ways of further usage of this principle. Aseev and Kryazhimskii (2007) proposes to extend the application of the Pontryagin maximum principle to a special class of problems arising when modeling the process of economic growth. Krasovskii and Tarasyev (2008) obtained models of economic growth using computer modeling. Mathematical justification and analysis of application of the Pontryagin maximum principle method (Pontryagin et al., 1962) allows to use it in the management of an optimization investment portfolio. Discussion is the use of the utility function to meet the financial interests of all participants in the proposed project. The form of the utility function reflects the attitude to the risk operations of the person making the decision. Considering that several investors participate in the formation of the investment portfolio, the same degree of their attitude to risk is assumed.

In his work Pavlov (2004) suggests considering a corporate system, which consists of the following participants: owners of the company, managers creditors, labor collective, and government. Special attention is paid to building a model of interaction between an owner and an investor. The problem of optimal management of enterprise's fixed assets is described taking into account the volume of output and its price, tax payments, depreciation charges and other factors affecting the enterprise net profit. When formulating the investor's strategy, the value of shares, dividends are paid for should be taken into account. Theoretical results of the optimal strategy for corporate system participants are given.

\section{CONCLUSION}

In the paper, the issue of investment portfolio management is considered. To create an optimal portfolio, the methods proposed by Markowitz, H. (1952) should be used. A portfolio is proposed to include only risk assets. A portfolio of maximum efficiency with risk restriction either a portfolio of minimum risk and given efficiency can be created. The issues of creating and introducing the necessary financial assets in the portfolio are not considered in this work and are the subject of different studies.

Having created an initial investment portfolio, the question of its financial development and fulfillment of investors' terms arises. Every investor wants to achieve its ultimate goal during the project's functioning. As a target function of a financial institution, an index of maximizing the net present value (NPV) of all the financial assets is considered, discounting included. The function of the target of an external investor is also the maximization of the investor's NPV as the difference between its discounted dividends and its discounted monetary investments. It is proposed to introduce the utility function as a general criterion for the strategy of its participants.

To fulfill all the requirements of potential investors, the Pontryagin maximum principle (Pontryagin et al., 1962) should be used. The criterion of optimal management used a function that shows how much of the income will be reinvested in portfolio assets. Analysis of numerical calculations showed that the distribution of OCF, in general, is of a decreasing nature. The nature of the distribution of OCF is practically independent of the amount of dividends paid $(d=0-0.3)$ (Figure 2). For a portfolio of 
greater efficiency, it is necessary to use less funds for its development than for a similar portfolio of lower yields (Figure 3). Figure 4 and Figure 5 show the OCF distribution as a function of the discount factor $\delta(0 ; 0.05$; $0,1)$. It is shown that the nature of the change in OCF is essentially dependent on the discount factor, while other parameters of the model increase linearly: $k$ from 0.1 to $0.9 ; d$ from 0 to $0.3 ; E_{p}$ from 0.1 to 0.3 . To a greater extent, this dependence is manifested in the early stages of investing a financial portfolio. Figure 5 shows that $\delta=0.1$ at the initial moment of investment, there is virtually no additional funds for investing in the portfolio. From time $t \approx 3.5$ the OCF distribution stabilizes at 0.35 regardless of the discount factor $(\delta=0-0.1)$.

Further development of the model assumes the use of other kinds of utility functions for finding the objective function of the proposed model, as well as finding the most adequate non-linear dependencies between the parameters of the model.

Thus, the strategy of investors' participation in formation of an investment portfolio is obtained, when observing optimal and mutually beneficial conditions for their coexistence in a financial project.

\section{References}

Artstein, Z. (2011). Pontryagin Maximum Principle Revisited with Feedbacks. European Journal of Control, 17 (1), 46-54.

Aseev, S.M. (2014). On some properties of the adjoint variable in the relations of the Pontryagin maximum principle for optimal economic growth problems. Proceedings of the Steklov Institute of Mathematics, 287 (S1), 11-21.

Aseev, S.M., \& Kryazhimskii, A.V. (2007). The Pontryagin Maximum Principle and Optimal Economic Growth Problems. Proceedings of the Steklov Institute of

\section{ОПТИМИЗАЦИЈА УПРАВЉАЫА ИНВЕСТИЦИОНИМ ПОРТФОЛИЈОМ}

\section{Viktor Oliinyk и Olga Kozmenko}

\section{Извод}

Разматран је задатак креирања инвестиционог портфолија од стране финансијске институције. Средства за израду портфолија узимају се из два извора: капитални фондови предузећа и позајмљена средства. Извршена је оптимизација креираног портфолија. Добијен је портфолио максималне ефикасности са ограничењем мере ризика који је наведен у облику ВпР (вредност при ризику) индикатора. Кориштењем података за оптимизацију портфолиа гради се модел управљања имовином портфолиа. Користећи Понтриагинов принцип максимума, утврђују се оптималне стратегије његових учесника. Пронађена је оптимална функција управљања инвестиционим портфолиом у виду удела добијеног дохотка. Приказани су нумерички резултати оптималног управљања инвестицијама у финансијском портфолију финансијске институције као и поверилаца.

Кључне речи:менаџмент, оптимизација, инвестиције, средства, ВпР 
Mathematics, 257 (1), 1-255.

Aseev, S., Hutschenreiter, G., Kryazhimskiy, A., \& Lysenko, A. (2005). A dynamic model of optimal investment in research and development with international knowledge spillovers. Mathematical and Computer Modeling of Dynamical Systems, 11 (2), 125-133.

Basak, S., \& Shapiro, A. (2001). Value-atRisk Based Risk Management: Optimal Policies and Asset Prices. Review of Financial Studies, 14 (2), 371-405.

Bender, J., Blackbur, T., \& Sun, X. (2019). Clash of the Titans: Factor Portfolios versus Alternative Weighting Schemes. The Journal of Portfolio Management Quantitative, 45 (3), 38-49.

Bilbao-Terol, A., Arenas-Parra, M., Cañal-Fernández, V., \& Bilbao-Terol, C. (2016). Multi-criteria decision making for choosing socially responsible investment within a behavioral portfolio theory framework: a new way of investing into a crisis environment. Annals of Operations Research, 247 (2), 549-580.

Blanchett, D., \& Ratner, H. (2015). Building Efficient Income Portfolios. The Journal of Portfolio Management, 41 (3), 117-125.

Burdorf, T., \& Van Vuuren, G. (2018). An evaluation and comparison of Value at Risk and Expected Shortfall. Investment Management and Financial Innovations, 15 (4), 17-34.

Calvo, C., Ivorra, C., \& Liern, V. (2018). Controlling risk through diversification in portfolio selection with non-historical information. Journal of the Operational Research Society, 69 (10), 1543-1548.

Danko, J., \& Šoltés, V. (2018). Portfolio creation using graph characteristics. Investment Management and Financial Innovations, 15 (1), 180-189.
Del Guercioa, D., Genc, E., \& Tran, H. (2018). Playing favorites: Conflicts of interest in mutual fund management. Journal of Financial Economics, 128 (3), 535-557.

Francq, C., \& Zakoïan, J.-M. (2018). Estimation risk for the VaR of portfolios driven by semi-parametric multivariate models. Journal of Econometrics, 205 (2), 381-401.

García-Melón, M., Pérez-Gladish, B., Gómez-Navarro, T., \& Mendez-Rodriguez, P. (2016). Assessing mutual funds' corporate social responsibility: a multistakeholderAHP based methodology. Annals of Operations Research, 244 (2), 475-503.

Germeier, Y.V. (1976). Games with nonopposite interests (in Russian). Nauka, Moscow.

Grinblatt, M., \& Saxena, K. (2018). When Factors Do Not Span Their Basis Portfolios. Journal of Financial and Quantitative Analysis, 53 (6), 2335-2354.

Hartl, R.F., Sethi, S.P., \& Vickson, R.G. (1995). A Survey of the Maximum Principles for Optimal Control Problems with State Constraints. SIAM Review, 37 (2), 181-218.

Holton, G.A. (2003). Value-at-Risk: theory and practice. Academic Press. San Diego. USA

Kalayci, C.B., Ertenlice, O., \& Akbay, M.A. (2019). A comprehensive review of deterministic models and applications for mean-variance portfolio optimization. Expert Systems with Applications, 125 (1), 345-368.

Kamien, M.I., \& Schwartz, N.L. (1971). Sufficient conditions in optimal control theory. Journal of Economic Theory, 3 (2), 207-214.

Koopmans, T.C. (1967). Objectives, Constraints, and Outcomes in Optimal Growth Models. Econometrica, 35 (1), 1-15. Krasovskii, A.A., \& Tarasyev, A.M. 
(2008). Conjugation of Hamiltonian Systems in Optimal Control Problems. Proceedings of the 17th IFAC World Congress, South Korea, 7784-7789.

Lester, A. (2019). On the Theory and Practice of Multifactor Portfolio. The Journal of Portfolio Management Quantitative, 45 (3), 87-100.

Li, J., Zhang, W., \& Kong, E. (2018). Factor models for asset returns based on transformed factors. Journal of Econometrics, 207 (2), 432-448.

Maheshwari, A., \& Sarantsev, A. (2018). Modeling Financial System with Interbank Flows, Borrowing, and Investing. Risks, 6 (4), 131.

Markowitz, H. (1952). Portfolio selection. The Journal of Finance, 7 (1), 77-91.

Mas-Colell, A., Whinston, M.D., \& Green, J.R. (1995). Microeconomic Theory. Oxford University Press, Oxford.

Mei, X., \& Nogales, F.J. (2018). Portfolio Selection with Proportional Transaction Costs and Predictability. Journal of Banking \& Finance, 94(C), 131-151. Oliinyk, V. (2017). Optimal Management of the Enterprise's Financial Flows. Journal of Advanced Research in Law and Economics, 8 (6), 1875-1883.

Oliynyk, V. (2015). Modeling of the optimal structure of insurance portfolio. Problems and Perspectives in Management, 13(2), 230-234.

Pavlov O.V. (2004). Dynamic models of interaction of participants in corporate systems (in Russian). Management of large systems: collection of paers, 8, 157-175.

Pontryagin, L.S, Boltyanskii, V.G, Gamkrelidze, R.V. \& Mishchenko, E.F. (1962). The mathematical theory of optimal processes. Intersciene Publishers John Wiley\&Sons, Inc. New York-London.

Post, T., Karabatı, S., \& Arvanitis, S.
(2018). Portfolio optimization based on stochastic dominance and empirical likelihood. Journal of Econometrics, 206 (1), 167-186.

Rockafellar, R., \& Uryasev, S. (2002). Conditional Value-at-Risk for General Loss Distributions. Journal of Banking \& Finance, 26 (7), 1443-1471.

Shalit, H., \& Yitzhaki, S. (1984). MeanGini, portfolio theory, and the pricing of risky assets. The Journal of Finance, 39 (5), 1449-1468.

Shell, K. (1969). Application of the Pontryagin's maximum principle to economics. In Lecture Notes in Operations Research and Mathematical Economics, 11. Mathematical system theory and economics, 1, 241-292, Berlin, Springer.

Simonian, J., \& Wu, C. (2019). Factors in Time: Fine-Tuning Hedge Fund Replication. The Journal of Portfolio Management Quantitative, 45 (3), 159-164.

Uhl, M.W., \& Rohner, P. (2018). The compensation portfolio. Finance Research Letters, 27, 60-64.

Van Gelderen, E., Huij, J., \& Kyosev, G. (2019). Factor Investing from Concept to Implementation. The Journal of Portfolio Management Quantitative, 45 (3) 125-140.

Zhang, W., Zhang, S., \& Zhao, P. (2019). On Double Value at Risk. Risks, 7 (1), 31.

Zhou, C., Wu, C., \& Wang, Y. (2019). Dynamic portfolio allocation with timevarying jump risk. Journal of Empirical Finance, 50, 113-124. 